BRITISH POLITICAL PARTIES 


\section{CONTEMPORARY POLITICAL STUDIES SERIES}

Series Editor: John Benyon, Director, Centre for the Study of Public Order, University of Leicester

A series which provides authoritative yet concise introductory accounts of key topics in contemporary political studies.

Other titles in the series include:

Pressure Groups, Politics and Democracy in Britain, 2nd edition WYN GRANT, University of Warwick

UK Political Parties since 1945

Edited by ANTHONY SELDON, Institute of Contemporary British History

Politics and Policy Making in Northern Ireland MICHAEL CONNOLLY, University of Ulster Local Government and Politics in Britain JOHN KINGDOM, Sheffield Hallam University

British Political Ideologies ROBERT LEACH, Leeds Metropolitan University

British Government: The Central Executive Territory PETER MADGWICK, Professor Emeritus, Oxford Brookes University Race and Politics in Britain SHAMIT SAGGAR, Queen Mary and Westfield College, University of London

Selecting the Party Leader MALCOLM PUNNETT, University of Strathclyde

Does Parliament Matter? PHILIP NORTON, University of Hull The President of the United States DAVID MERVIN, University of Warwick The Politics of Economic Policy WYN GRANT, University of Warwick Introduction to International Politics DEREK HEATER, formerly of Brighton University and G.R. BERRIDGE, University of Leicester

Elections and Voting Behaviour in Britain, 2nd edition DAVID DENVER, Lancaster University

The Law and Politics of the British Constitution of the United Kingdom 


\title{
BRITISH POLITICAL PARTIES
}

\author{
JUSTIN FISHER
}

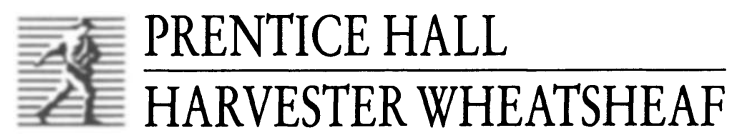

LONDON NEW YORK TORONTO SYDNEY TOKYO SINGAPORE MADRID MEXICO CITY MUNICH 
First published 1996 by

Prentice Hall Europe

Campus 400, Maylands Avenue

Hemel Hempstead

Hertfordshire, HP2 7EZ

A division of

Simon \& Schuster International Group

ISBN 978-0-333-76326-1 ISBN 978-1-349-15024-3 (eBook)

DOI 10.1007/978-1-349-15024-3

(C) Prentice Hall Europe 1996

Reprint of the original edition 1996

All rights reserved. No part of this publication may be reproduced, stored in a retrieval system, or transmitted, in any form, or by any means, electronic, mechanical, photocopying, recording or otherwise, without prior permission, in writing, from the publisher.

Typeset in 10/12pt Times

by Dorwyn Ltd, Rowlands Castle, Hants

Library of Congress Cataloging-in-Publication Data

Fisher, Justin.

British political parties/Justin Fisher.

p. cm.-(Contemporary political studies)

Includes bibliographical references and index.

ISBN 978-0-333-76326-1(pbk. : alk. paper)

1. Political parties-Great Britain. I. Title.

II. Series.

JN1 121.F573 1996

$324.241-\mathrm{dc} 20$

British Library Cataloguing in Publication Data

A catalogue record for this book is available from the British Library

ISBN 978-0-13-353806-9

$\begin{array}{llllllll}2 & 3 & 4 & 5 & 00 & 99 & 98 & 97\end{array}$ 


\section{CONTENTS}

Preface

ix

I THE DEVELOPMENT OF BRITISH POLITICAL PARTIES AND THE BRITISH PARTY SYSTEM

Introduction

The modern British political party 2

$\begin{array}{ll}\text { The development of the British party system } & 8\end{array}$

Factors influencing the development of the party system 15

$\begin{array}{ll}\text { Conclusions } & 17\end{array}$

2 THE ROLE OF POLITICAL PARTIES IN BRITAIN TODAY 19 Introduction $\quad 19$

Electoral choice $\quad 19$

Representation $\quad 20$

Policy making $\quad 23$

Recruitment and the selection of parliamentary candidates $\quad 24$

Political education and communication $\quad 25$

Political participation $\quad 26$

Are British parties in decline? $\quad 27$

Conclusions $\quad 32$

3 THE CONSERVATIVE PARTY 33

Introduction $\quad 33$

Organisation and internal elections $\quad 33$

$\begin{array}{ll}\text { The election of the leader } & 38\end{array}$

The selection of parliamentary candidates $\quad 45$ 
The social background of Conservative MPs and candidates 45

$\begin{array}{ll}\text { Funding } & 48\end{array}$

Ideology 51

Measuring ideological change $\quad 55$

Groupings and factions $\quad 57$

Recent history 61

$\begin{array}{ll}\text { Conclusions } & 63\end{array}$

4 THE LABOUR PARTY 64

Introduction $\quad 64$

Organisation and internal elections $\quad 65$

$\begin{array}{ll}\text { The role of the trade unions } & 67\end{array}$

The election of the leader 71

The selection of parliamentary candidates $\quad 73$

$\begin{array}{ll}\text { Sponsorship of candidates and MPs } & 74\end{array}$

The social background of Labour MPs and candidates 76

$\begin{array}{ll}\text { Funding } & 78\end{array}$

Ideology $\quad 80$

Measuring ideological change $\quad 86$

$\begin{array}{ll}\text { Groupings and factions } & 87\end{array}$

Recent history $\quad 90$

Conclusions $\quad 92$

5 THE LIBERAL DEMOCRATS 94

Introduction $\quad 94$

Organisation and internal elections $\quad 95$

The election of the leader $\quad 99$

The selection of parliamentary candidates 99

The social background of Liberal Democrat MPs and candidates $\quad 100$

Funding $\quad 102$

$\begin{array}{ll}\text { Ideology } & 104\end{array}$

Measuring ideological change III

$\begin{array}{ll}\text { Groupings and factions } & 113\end{array}$

$\begin{array}{ll}\text { Recent history } & 114\end{array}$

$\begin{array}{ll}\text { Conclusions } & \text { II5 }\end{array}$

6 THE 'OTHERS' IN THE BRITISH PARTY SYSTEM 116

Introduction $\quad 116$

$\begin{array}{ll}\text { Nationalist parties in Britain } & 117\end{array}$

$\begin{array}{ll}\text { The Scottish National Party } & 118\end{array}$ 
Plaid Cymru

The parties of Northern Ireland

Conclusions

7 THE PARTY MEMBERS

Introduction

The role of party members

Who are the party members?

The views of party members on political issues

The views of party members on their own parties

Party activism

Conclusions

8 VOTING AND ELECTIONS

Introduction

Trends in election results

Studies of voting behaviour

Evidence from the 1992 General Election

Conclusions

9 CONCLUSION

Parties and their functions

British political parties and the future

Appendices

References and Bibliography 


\section{PREFACE}

Political parties are an established feature of British democracy. They are also an essential one and play a role in many aspects of political life. However, studying parties can be a difficult process. Some parties are more widely studied than others. Inevitably, there is relatively little academic work on the Liberal Democrats given their comparative youth. Yet the Labour Party has generated an enormous literature, whilst its elder rival the Conservative Party, has not been studied to anything like the same extent, though in the past few years this imbalance has been partially redressed. Moreover, some essential aspects of political parties have been examined more closely than others. Party finance is one area that has attracted comparatively little work, whilst party members were virtually ignored before the beginning of this decade.

My aim in this book is to bring together the main features of the political parties and examine them in a way which allows for both study of one party, comparisons with others and analysis of the strengths and weaknesses of political parties in Britain. In a book of this type, one cannot develop great detail on every topic. However, I hope that I have covered most of the principal considerations as well as providing a pointer to the wider literature.

The preparation of this book has left me indebted to many people. Firstly, I am grateful to Avebury Publishing Ltd, Faber \& Faber Ltd, Macmillan Press Ltd, Oxford University Press, American Enterprise Institute Press, Patrick Seyd and Pippa Norris for permission to reproduce material. Secondly, I am grateful to the 
ESRC Data Archive at the University of Essex for supplying data from the British Election Survey 1992. Thirdly, I am indebted to the following for their advice and help: David Broughton, David Denver, Bob Self and Paul Webb. Their advice has been sound and always constructive, though I alone am responsible for any errors of interpretation. Fourthly, I am grateful to Clare Grist, Ruth Pratten and Ian MacQuarrie at Prentice Hall for their drive, calm efficiency and patience. Finally, there are many personal debts and acknowledgements: to Jackie, a woman who is always loving and supportive, my step-daughter Anja, our child-minder Beryl and my colleagues in the Department of Politics \& Modern History at London Guildhall University who have provided such a convivial atmosphere in which to work.

The course of writing this book has been a very happy one. I have watched our son, Lewis, learn to walk, begin to talk and love his favourite football team - Brentford. I have also had the pleasure (but not the pain!) of the birth of our daughter, Edie - also a Brentford fan. To them, I dedicate this book. 